\title{
Cold gel-like emulsions of lactoferrin subjected to ohmic heating
}

\author{
Guilherme de Figueiredo Furtado $^{\mathrm{a}}$, Ricardo Nuno Correia Pereira ${ }^{\mathrm{b}}$, António Augusto Vicente ${ }^{\mathrm{b}, *}$, \\ Rosiane Lopes Cunha ${ }^{a}$ \\ a Department of Food Engineering, School of Food Engineering, University of Campinas, 13083-862 Campinas, SP, Brazil \\ b CEB - Centre of Biological Engineering, University of Minho, 4710-057 Braga, Portugal
}

\section{A R T I C L E I N F O}

\section{Keywords:}

Gel-like emulsions

Lactoferrin

Ohmic heating

Rheological properties

\begin{abstract}
A B S T R A C T
Ohmic heating is a technique that has gained increasing attention because of its capacity to produce uniform heating, and claimed electrical influence on the functional and technological properties of treated protein dispersions. The aim of this work was to evaluate the influence of ohmic heating on the properties of cold gel-like emulsions, comparing them with those obtained by conventional heating. The effect of ohmic and conventional heating on physical and structural properties of lactoferrin was also addressed. Ohmic heating treatment resulted in less pronounced aggregation of lactoferrin, when compared to conventional heating. An increase of particle size, turbidity, intrinsic and extrinsic fluorescence values and a decrease of dichroic signal after heat treatment indicated an increase of protein interactions. Emulsions produced from heat-treated lactoferrin showed gel-like behavior which was related to the emulsifying capacity of lactoferrin, combined with the emulsification method and the heat pre-treatment applied to the protein. Rheological and microstructural properties were intrinsically related to the heat treatment of the protein since ohmic heating produced gel-like emulsions with a less rigid structure. These emulsions could be interesting for food applications containing heat-sensitive ingredients.
\end{abstract}

\section{Introduction}

Emulsions tend to be destabilized by several mechanisms like aggregation, phase inversion, flocculation and coalescence, thus being considered as thermodynamically unstable systems (Dickinson, 1997), but a kinetic stability for a considerable time can be reached with the addition of emulsifiers (McClements, Decker, \& Weiss, 2007). Milk proteins are widely used to form and stabilize oil-in-water emulsions, and this functionality is related to their capacity to be adsorbed onto the water-oil interface (Dalgleish, 1997; Dickinson, 1997). Recently, works have shown the potential of utilization of lactoferrin as an emulsifier (Furtado, Mantovani, Consoli, Hubinger, \& Cunha, 2017; Pinheiro, Coimbra, \& Vicente, 2016; Sarkar, Goh, \& Singh, 2009; Sarkar, Horne, \& Singh, 2010; Tokle \& McClements, 2011). This protein presents a globular structure with a single polypeptide chain of about $80 \mathrm{kDa}$ (containing one to four glycans) and high isoelectric point (pI $\approx$ 8.6-8.9) (Spik et al., 1994; Steijns \& van Hooijdonk, 2000) attributed to the high content of basic amino acids. Furthermore, lactoferrin shows a number of biological functions, which can include antioxidant, antimicrobial, antiviral and anticancer activity (Wakabayashi, Yamauchi, \& Takase, 2006) making it a very desirable functional ingredient to be incorporated into food formulations.
Whey protein stabilized emulsions can be transformed into gelled emulsions by traditional techniques, such as heat treatment (Chen, Dickinson, Langton, \& Hermansson, 2000; Liu \& Tang, 2011), acidification with glucono- $\delta$-lactone (GDL) (Boutin, Giroux, Paquin, \& Britten, 2007; Ye \& Taylor, 2009) and addition of salts of divalent ions (e.g. $\mathrm{CaCl}_{2}$ ) (Sok Line, Remondetto, \& Subirade, 2005; Ye \& Taylor, 2009). As lactoferrin is a globular protein (Damodaran, Parkin, \& Fennema, 2007) we hypothesize it could form gels. Previous studies investigated the formation of nanohydrogels (Bourbon et al., 2015) and viscoelastic gels from heated emulsion stabilized by lactoferrin (Tokle \& McClements, 2011). However, to our knowledge there are no previous studies about the production of cold gel-like emulsions with lactoferrin.

The heat treatment necessary to produce gelled emulsions limits their application in formulations containing heat-sensitive ingredients, such as bioactives, while those obtained by cold-set techniques (without heat treatment) are more favorable (Liu \& Tang, 2011; Sok Line et al., 2005) and exhibit some enhanced functional characteristics - e.g. controlled release of bioactives and improved oxidative stability of lipids (Lee, Choi, \& Moon, 2006). However, in cold-set techniques, a heat treatment of protein dispersions before emulsification step is needed to ensure denaturation of the protein native structure. This denaturation is

\footnotetext{
* Corresponding author.

E-mail addresses: furtado.gf@gmail.com (G. de Figueiredo Furtado), rpereira@deb.uminho.pt (R.N.C. Pereira), avicente@deb.uminho.pt (A.A. Vicente), rosiane@unicamp.br (R.L. Cunha).
} 
characterized by the formation of soluble aggregates (Boutin et al., 2007; Sok Line et al., 2005) through the partial unfolding of the native protein, and a subsequent aggregation of unfolded molecules (Nielsen, Singh, \& Latham, 1996). These soluble aggregates will act as "building blocks" necessary for the development of protein network systems, such as gels (Pereira et al., 2016). Subsequent addition of salts with divalent ions, such as $\mathrm{CaCl}_{2}$, can be done, improving cross-linking of proteins and thus promoting gelation (Bryant \& McClements, 2000; Kuhn, Cavallieri, \& Da Cunha, 2010, 2011).

Ohmic heating $(\mathrm{OH})$ has been receiving increased attention due to its volumetric heating and rapid heating rates that enable high temperatures to be applied in a short-time, thus allowing to obtain products of a superior quality to those processed by conventional heating technologies (Castro, Teixeira, Salengke, Sastry, \& Vicente, 2003; Machado, Pereira, Martins, Teixeira, \& Vicente, 2010; Rodrigues et al., 2015). During $\mathrm{OH}$ treatment the food product to be treated behaves as an electrical resistance, allowing the passage of an alternating electric current through it which results in generation of internal heat, according to Joule's law (De Alwis \& Fryer, 1990). The presence of the inherent electric variables of $\mathrm{OH}$ (i.e. electric field, electric frequency and current density) lead to protein conformational disturbances and distinct gelation behavior during heat-induced denaturation of whey protein isolate (Pereira, Souza, Cerqueira, Teixeira, \& Vicente, 2010; Pereira, Teixeira, \& Vicente, 2011; Rodrigues et al., 2015). However, there are no particular studies about the influence of $\mathrm{OH}$ on lactoferrin properties.

The objective of this work was to produce cold gel-like emulsions from ohmic heated lactoferrin dispersions. These gelled emulsions were characterized in terms of their physical and structural properties and compared with emulsions produced using a conventional heating method. The effect of ohmic and conventional heating on the protein secondary structure and consequent thermal aggregation of lactoferrin were evaluated in order to provide insight to the mechanisms that may be influencing the observed changes in gelled emulsions properties.

\section{Materials and methods}

\subsection{Materials}

Lactoferrin from bovine milk (protein content $92.1 \mathrm{wt} \%$, iron saturation 9.9\%) was kindly provided by Synlait Milk Ltd. (Canterbury, New Zealand) and sunflower oil (Fula, Portugal) was purchased in a local market. The other reagents were of analytical grade.

\subsection{Methods}

\subsubsection{Preparation of lactoferrin dispersion}

Lactoferrin (3.0 wt \%) was dispersed in $20 \mathrm{mM}$ sodium phosphate buffer ( $\mathrm{pH}$ 6.0) using magnetic stirring overnight at room temperature, ensuring complete dissolution of the protein. Electrical conductivity of the prepared lactoferrin dispersion was approximately $1.5 \mathrm{mS} \cdot \mathrm{cm}^{-1}$ (WTW LF 538 conductivity meter, Weilheim, Germany), which allowed the ohmic heating effect to take place.

\subsubsection{Conventional heating $(\mathrm{CH})$ of lactoferrin dispersion}

A double-walled water jacketed glass reactor vessel $(30 \mathrm{~mm}$ of internal diameter and $100 \mathrm{~mm}$ in height) was used, as previously reported by Pereira et al. (2010). Temperature was controlled by circulating thermostabilized water from a bath. A magnetic stirrer was used to homogenize lactoferrin dispersion, improving heat transfer during the heating cycle. Temperature was measured online with a type $\mathrm{K}$ thermocouple (accuracy of $\pm 1{ }^{\circ} \mathrm{C}$; Omega Engineering, Inc., Stamford, CT, USA), placed at the center of the sample volume, and connected to an acquisition system (USB-9161, National Instruments Corporation, Austin, TX, USA), as described by Pereira et al. (2016).

\subsubsection{Ohmic heating $(\mathrm{OH})$ of lactoferrin dispersion}

Experiments were performed in a cylindrical glass tube of $30 \mathrm{~cm}$ total length and an inner diameter of $2.3 \mathrm{~cm}$, with two stainless steel electrodes isolated at each edge with polytetrafluoroethylene (PTFE) caps, as previously reported by Pereira et al. (2010). A gap between the electrodes of $4 \mathrm{~cm}$ was used, and the supplied voltage ranged from 36 to $86 \mathrm{~V}$. The sample temperature was controlled through regulation of the supplied voltage using a function generator $(1 \mathrm{~Hz}-25 \mathrm{MHz}$ and 1 to $10 \mathrm{~V}$; Agilent 33220A, Penang, Malaysia) connected to an amplifier device (Peavey CS3000, Meridian, MS, USA). The voltage was adjusted to simulate the thermal history of samples treated by $\mathrm{CH}$, allowing to discriminate the existence of additional non-thermal effects on denaturation of proteins due to the presence of electric variables (Pereira et al., 2017). To eliminate different shearing conditions between treatments, sample volume and stirring conditions were identical, as described previously for $\mathrm{CH}$ treatment.

\subsubsection{Heating conditions of lactoferrin dispersion}

Lactoferrin dispersion $(20 \mathrm{~mL})$ was heated at $90{ }^{\circ} \mathrm{C}$ for $30 \mathrm{~min}$ through $\mathrm{CH}$ or $\mathrm{OH}$. After a heating come-up time (time to raise temperature from 25 to $90{ }^{\circ} \mathrm{C}$ ), the temperature was held constant at $90{ }^{\circ} \mathrm{C}$ for $30 \mathrm{~min}$. The temperature profile was quite similar for $\mathrm{CH}$ and $\mathrm{OH}$ (Fig. 1) which allowed to evaluate the non-thermal effects (or electric effects) of $\mathrm{OH}$ treatment. The temperature used was based on the thermal behavior of native bovine lactoferrin, that presents two denaturation peaks around 60 and $89^{\circ} \mathrm{C}$, respectively (Bengoechea, Peinado, \& McClements, 2011; Bokkhim, Bansal, Grøndahl, \& Bhandari, 2013).

\subsubsection{Characterization of lactoferrin dispersion}

2.2.5.1. Turbidity. The turbidity of undiluted protein dispersions was analyzed using an UV/visible spectrophotometer at $600 \mathrm{~nm}$ (Synergy HT, Bio-Tek, Winooski, USA), according to Bengoechea et al. (2011). The sodium phosphate buffer described previously ( $20 \mathrm{mM}$ at $\mathrm{pH} 6.0$ ) was used as blank measurement.

2.2.5.2. Intrinsic fluorescence. Intrinsic fluorescence spectra of the protein dispersions $(0.01 \mathrm{wt} \%)$ were obtained at $20{ }^{\circ} \mathrm{C}$ using a spectrofluorimeter (Horiba Scientific, USA) equipped with a standard

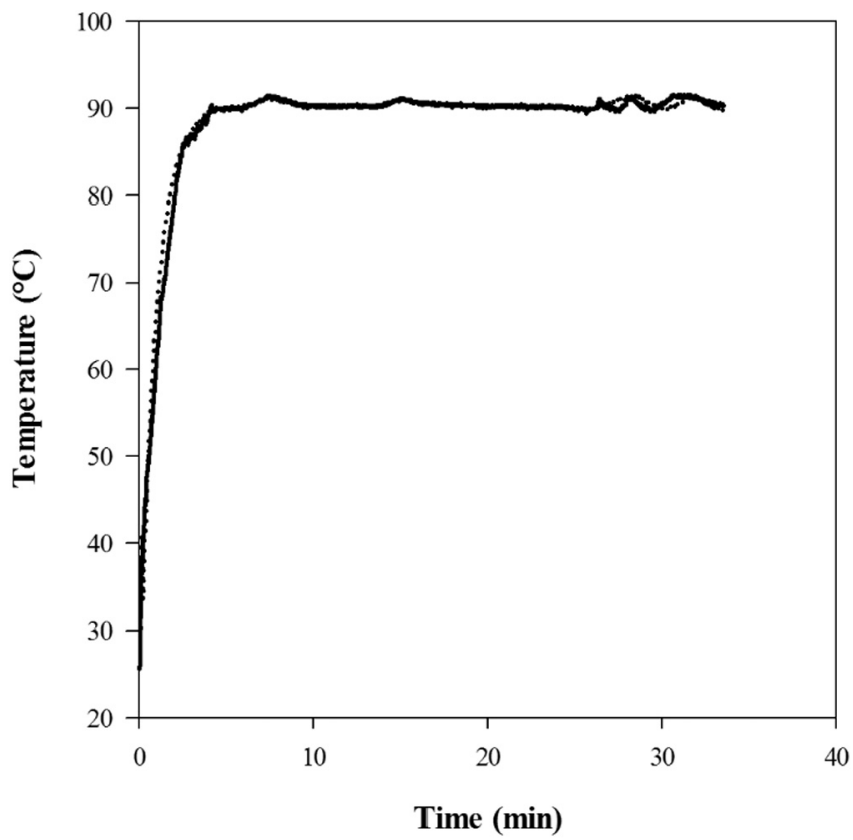

Fig. 1. Example of similar thermal histories at $90{ }^{\circ} \mathrm{C}$ for conventional (dotted line) and ohmic (solid line) heating treatments. 
thermostated cell holder and a $1.0 \mathrm{~cm}$ path length quartz cuvette. The excitation wavelength was $290 \mathrm{~nm}$. Emission spectra were recorded between 300 and $400 \mathrm{~nm}$ with $1 \%$ attenuation, and fluorescence intensities were recorded every $0.5 \mathrm{~nm}$.

2.2.5.3. Extrinsic fluorescence. For the extrinsic fluorescence, lactoferrin dispersion $(3 \mu \mathrm{M})$ was incubated at $20{ }^{\circ} \mathrm{C}$ with a 50 -fold molar excess of freshly prepared 8-anilo-1-naphthalenesulfonate (ANS) (Sigma-Aldrich, St. Louis, EUA) for $60 \mathrm{~min}$ in the dark before the analysis. The excitation was fixed at $365 \mathrm{~nm}$ and the emission was collected between 400 and $600 \mathrm{~nm}$ at $20^{\circ} \mathrm{C}$, using a $1.0 \mathrm{~cm}$ path length quartz cuvette. Spectra of ANS fluorescence were acquired with a spectrofluorimeter (Horiba Scientific, USA) (Stroylova et al., 2011).

2.2.5.4. Free sulfhydryl groups. Free sulfhydryl (SH) groups on lactoferrin dispersion were determined on heat-treated samples using Ellman's 5,5-dithiobis-2-nitrobenzoicacid (DTNB) method, as described in previous literature (Pereira et al., 2010).

2.2.5.5. Hydrodynamic diameter and polydispersity index. Particle size measurements were made by dynamic light scattering (DLS) using a Zetasizer Nano Series (Malvern Instruments, Worcestershire, UK). Unheated and heat-treated samples $(0.01 \mathrm{wt} \%, 2 \mathrm{~mL})$ were poured into sizing cuvettes and measurements were carried out, at least, in triplicate. The temperature of the cell was maintained at $20^{\circ} \mathrm{C}$. The method of cumulant fit was used to translate the average diffusion coefficients into average particle diameters (Z-Average value) using Stokes-Einstein relationship (Anema \& Li, 2003). The polydispersity index (PDI) describes the width or the relative variance of the particle size distribution and was based on the measurements of dynamic light scattering intensity autocorrelation function.

2.2.5.6. Far-UV circular dichroism (CD). Far-UV circular dichroism was used to investigate the secondary structure of untreated and heattreated lactoferrin. Protein dispersions $(0.01 \mathrm{wt} \%)$ were evaluated at $20{ }^{\circ} \mathrm{C}$ in the spectral range from 190 to $260 \mathrm{~nm}$ with a spectropolarimeter (Jasco J-1500, Jasco Corp., Japan), using a quartz cuvette with an optical path of $0.1 \mathrm{~cm}$. Scan speed was set to $50 \mathrm{~nm} /$ min and three scans were accumulated and averaged. All the spectra were corrected using a protein-free sample.

\subsubsection{Emulsion preparation}

Emulsions were prepared by homogenizing $10 \%(\mathrm{v} / \mathrm{v})$ of sunflower oil with $90 \%(\mathrm{v} / \mathrm{v})$ of preheated lactoferrin dispersion, using an UltraTurrax homogenizer ( $\mathrm{T}$ 25, Ika, Germany) at $15,000 \mathrm{rpm}$ for $2 \mathrm{~min}$ followed by passage through a high pressure homogenizer (NanoDeBee, Bee International, South Easton, Massachusetts, USA) at 137.9 MPa, according to Pinheiro et al. (2016). A divalent salt was used to induce cold-set gelation. Thus, emulsions were mixed with a concentrated $\mathrm{CaCl}_{2}$ solution to obtain a final concentration of $60 \mathrm{mM}$ by vortexing at room temperature, as previously described by Sok Line et al. (2005). The emulsions were stored at room temperature for $24 \mathrm{~h}$ prior to further analysis.

\subsubsection{Emulsions characterization}

2.2.7.1. Droplet size. Droplet size was measured by dynamic light scattering (DLS) using a Zetasizer Nano Series (Malvern Instruments, Worcestershire, UK). Samples were diluted $(0.01 \mathrm{wt} \%, 2 \mathrm{~mL})$ in the same buffer of lactoferrin dispersion $(20 \mathrm{mM}$ sodium phosphate buffer, $\mathrm{pH}$ 6.0). They were poured into sizing cuvettes and measurements were carried out, at least, in triplicate. The temperature of the cell was maintained at $20^{\circ} \mathrm{C}$.

2.2.7.2. Rheology. Rheological measurements of the emulsions were performed using a rheometer Discovery HR-1 (TA Instruments, New Castle, USA) with a stainless-steel cone plate geometry $\left(60 \mathrm{~mm}, 2^{\circ}\right.$ angle, truncation $64 \mu \mathrm{m}$ ). Flow curves were obtained by an up-down-up steps program with shear rate ranging from 0 to $300 \mathrm{~s}^{-1}$. Newtonian (Eq. (1)) and power law model (Eq. (2)) were fitted to the data to obtain the rheological properties. Viscoelastic behavior of samples was determined from oscillatory measurements using a frequency sweep between 0.1 and $10 \mathrm{~Hz}$ performed within the linear viscoelasticity domain. These measurements were done at $20{ }^{\circ} \mathrm{C}$ after one day of samples storage. The contribution of the elastic and viscous characteristics was evaluated from storage $\left(G^{\prime}\right)$ and loss $\left(G^{\prime \prime}\right)$ moduli, respectively. Preliminary measurements were done in order to identify the linear viscoelastic region by measuring the shear moduli at different strain values at a fixed frequency $(1 \mathrm{~Hz})$, where a constant strain of $1 \%$ was used for the subsequent measurements.

$\sigma=\eta \cdot \dot{\gamma}$

$\sigma=k \cdot \dot{\gamma}^{n}$

where $\sigma$ is the shear stress (Pa), $\eta$ is the viscosity (Pa-s), $\dot{\gamma}$ is the shear rate $\left(\mathrm{s}^{-1}\right), k$ is the consistency index $\left(\mathrm{Pa} \cdot \mathrm{s}^{\mathrm{n}}\right)$ and $n$ is the flow behavior index (dimensionless).

2.2.7.3. Microstructure. Emulsions were analyzed using an epifluorescence microscope (Olympus BX51) coupled with a DP71 digital camera and three sets of filters in the range of 360-370/420; 470-490/520; and 530-550/590 (Olympus Portugal SA, Porto, Portugal). All images were acquired using the Olympus cellSens software. Sunflower oil was stained with Nile Red (0.005 wt\%).

\subsection{Statistical analysis}

The experiments were run in triplicate, and all measured parameters are means of nine experimental points. The results were evaluated by one-way analysis of variance (ANOVA), and significant differences $(p<0.05)$ between the treatments were evaluated by the Tukey procedure. The statistical analyses were performed using a trial version of the software Minitab 16.1.0 (Minitab Inc., State College, PA, USA).

\section{Results and discussion}

\subsection{Characterization of lactoferrin dispersion}

Turbidity values of lactoferrin dispersion increased with heating time for both treatments. However, $\mathrm{OH}$ resulted in a lower turbidity value, indicating less protein aggregation than in conventional heating (Fig. 2). This effect may be attributed to the increase of more reactive (unfolded) globular protein molecules at higher temperatures, enhancing protein-protein collision frequency, thus favoring protein aggregation (Bengoechea et al., 2011).

The average hydrodynamic diameter (Z-Average) increased considerably in both treatments. However, $\mathrm{OH}$ produced smaller protein aggregates $(p<0.05)$ when compared with $\mathrm{CH}$ (Fig. 3a). Lactoferrin dispersions heated $30 \mathrm{~min}$ by $\mathrm{CH}$ presented Z-Average of $76.0 \pm 0.7 \mathrm{~nm}$ while $\mathrm{OH}$ showed a value of $68.7 \pm 0.4 \mathrm{~nm}$. PDI values decreased after heating, reaching a value of 0.2 for both treatments (Fig. 3b). Fig. 3c shows the size distribution curves obtained for unheated lactoferrin dispersions and after heating at $90^{\circ} \mathrm{C}$. Size distribution curves of unheated lactoferrin dispersions showed a first population with a maximum located around $10 \mathrm{~nm}$ that refers to lactoferrin monomers (Tavares et al., 2015), a second population with a maximum between 10 and $100 \mathrm{~nm}$, and a third peak between 100 and $1000 \mathrm{~nm}$ that could be some aggregates. When lactoferrin dispersions were heated at $90{ }^{\circ} \mathrm{C}$, the first and third population disappeared with a concomitant increase of the middle peak. These results are in agreement with previous works that observed size increase after heating (Pereira et al., 2010; Rodrigues et al., 2015), and also corroborates turbidity results. 


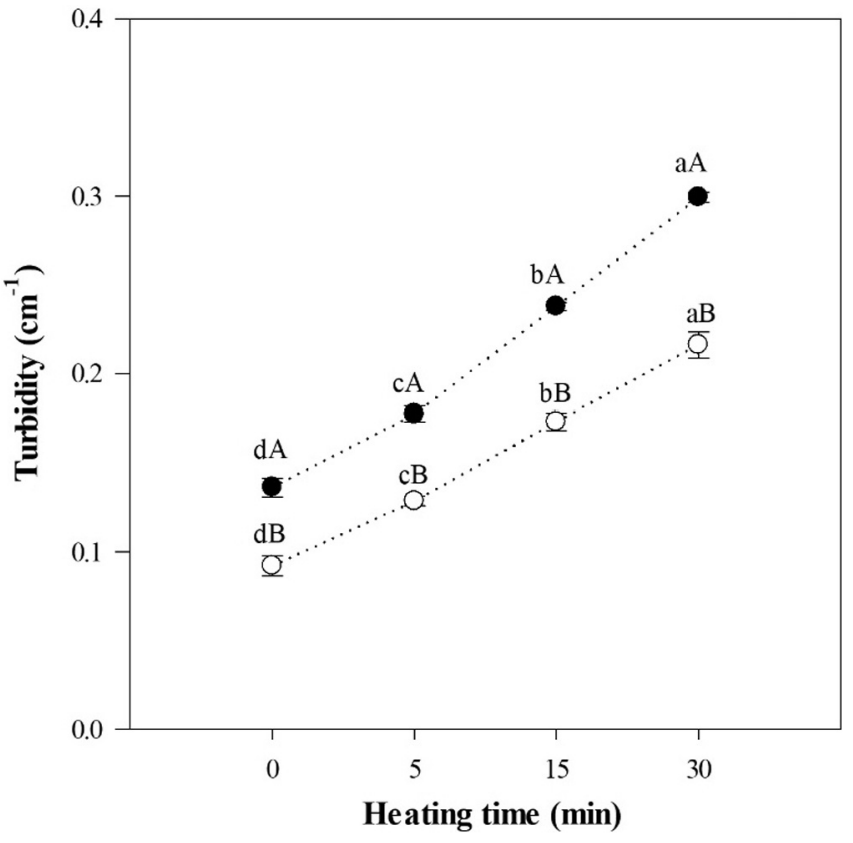

Fig. 2. Turbidity values of lactoferrin dispersions after different times of conventional (full symbols) or ohmic (empty symbols) heating. Different lowercase letters represent significant differences $(p<0.05)$ between heating time and different uppercase letters represent significant differences $(p<0.05)$ between heating treatments.

Local disturbances and changes on protein structure and dynamics are widely accessed through intrinsic tryptophan fluorescence measurements (Vivian \& Callis, 2001). Then, this analysis was performed in order to investigate the effect of heating time on the conformational and structural changes of lactoferrin. An increase of fluorescence intensity was observed with increasing heating time of protein dispersions, but no significant differences were observed between both treatments after $30 \mathrm{~min}$ of heating (Fig. 4a). This increase in fluorescence intensity may be related to changes in the conformational structure of the protein molecule due to molecular local unfolding, allowing exposure of buried tryptophan residues (Bourbon et al., 2015; Royer, 2006; Stănciuc et al., 2013). The averaged emission fluorescence spectra for tryptophans, contained in different parts of lactoferrin, showed a maximum emission band near $336 \mathrm{~nm}$ (Fig. 4a), which is in agreement with previous works (Bourbon et al., 2015; Fang et al., 2014). The red shift of the wavelength of maximum fluorescence intensity indicates a considerable increase of the accessibility of these residues to the solvent (Uversky, Narizhneva, Kirschstein, Winter, \& Löber, 1997).

ANS fluorescence measurements on the lactoferrin dispersions were performed in order to provide information about variation of the accessible hydrophobic areas. Fig. 4b shows that an increase in heating time was accompanied by significant changes in the intensity of ANS fluorescence, probably due to progressive unfolding of the protein and increasing accessibility of ANS probe to the protein hydrophobic core. This increase in extrinsic fluorescence intensity corroborates with intrinsic fluorescence results. However, hydrophobic groups of lactoferrin treated by $\mathrm{OH}$ were less prone to react with ANS than conventional heated ones. As the ANS is anionic, electrostatic interactions may have occurred with lactoferrin due to its basic character. The interaction of ANS with exposed hydrophobic groups of the protein due to heating is accompanied by a considerable increase in the dye fluorescence intensity and a pronounced blue shift of the maximum fluorescence (Stănciuc et al., 2013). However, a slight blue shift in wavelength for ANS fluorescence was observed (Fig. 4b). Probably, the lower denaturation/aggregation of $\mathrm{OH}$-induced lactoferrin led to changes at the conformational level making these hydrophobic groups less exposed to
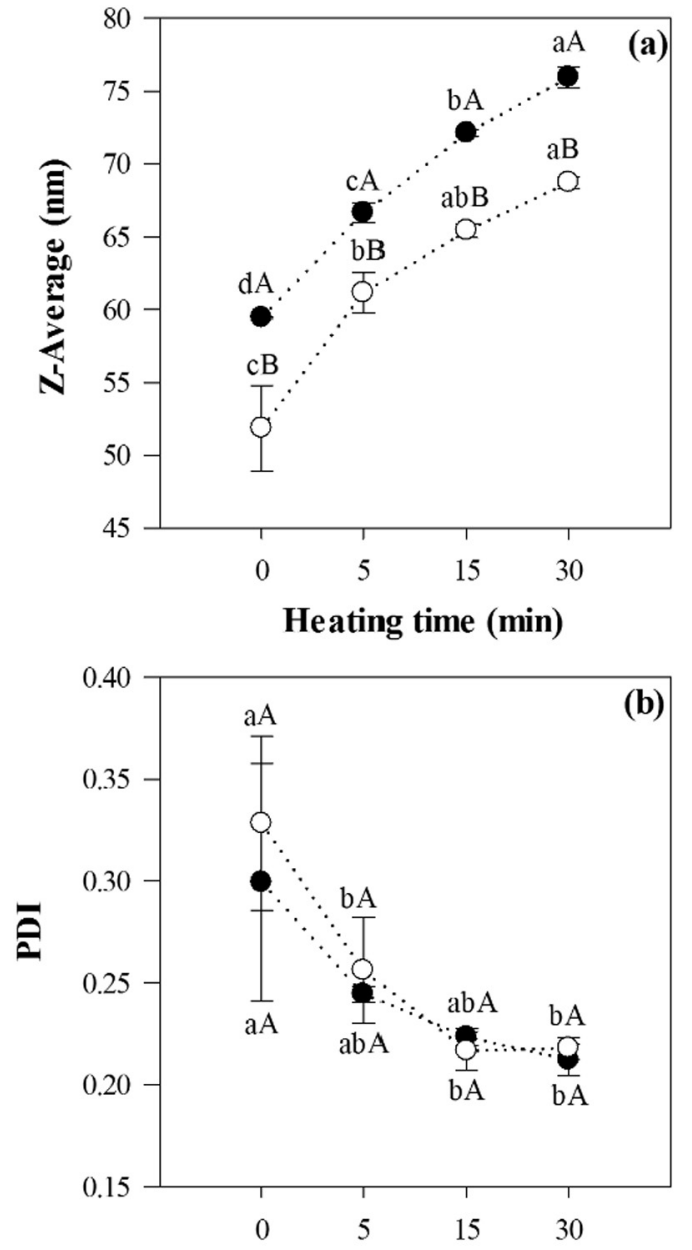

Heating time (min)

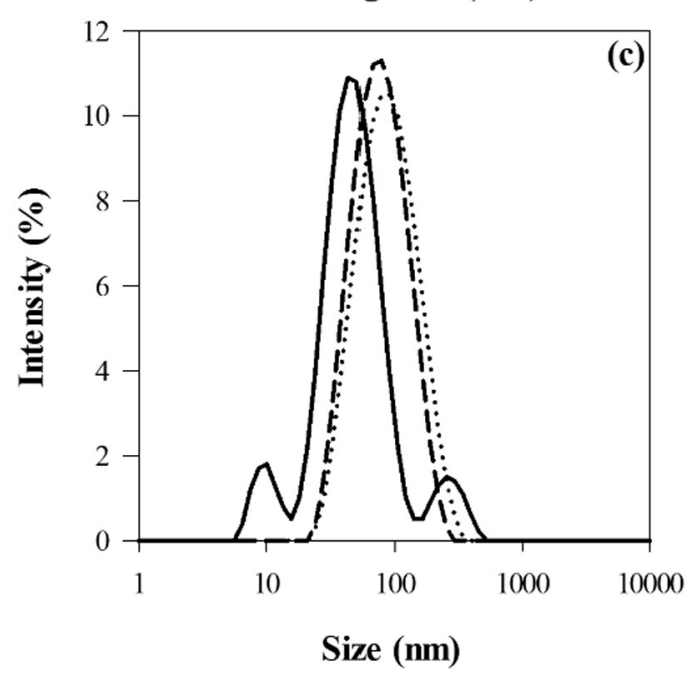

Fig. 3. Z-Average (a), PDI (b) and particle size distribution (c) of unheated and thermally heated lactoferrin dispersions. Unheated lactoferrin (solid line), CH-heated lactoferrin (dotted line or full symbols) and OH-heated lactoferrin (dashed line or empty symbols). Different lowercase letters represent significant differences $(p<0.05)$ between heating time and different uppercase letters represent significant differences $(p<0.05)$ between heating treatments.

ANS.

The content of free SH groups was very low, ranging from $\approx 0.005$ to $0.030 \mu \mathrm{mol} / \mathrm{g}$ (Fig. 5). This was somehow expected once lactoferrin in its native state contains intramolecular disulfide bonds but no free 

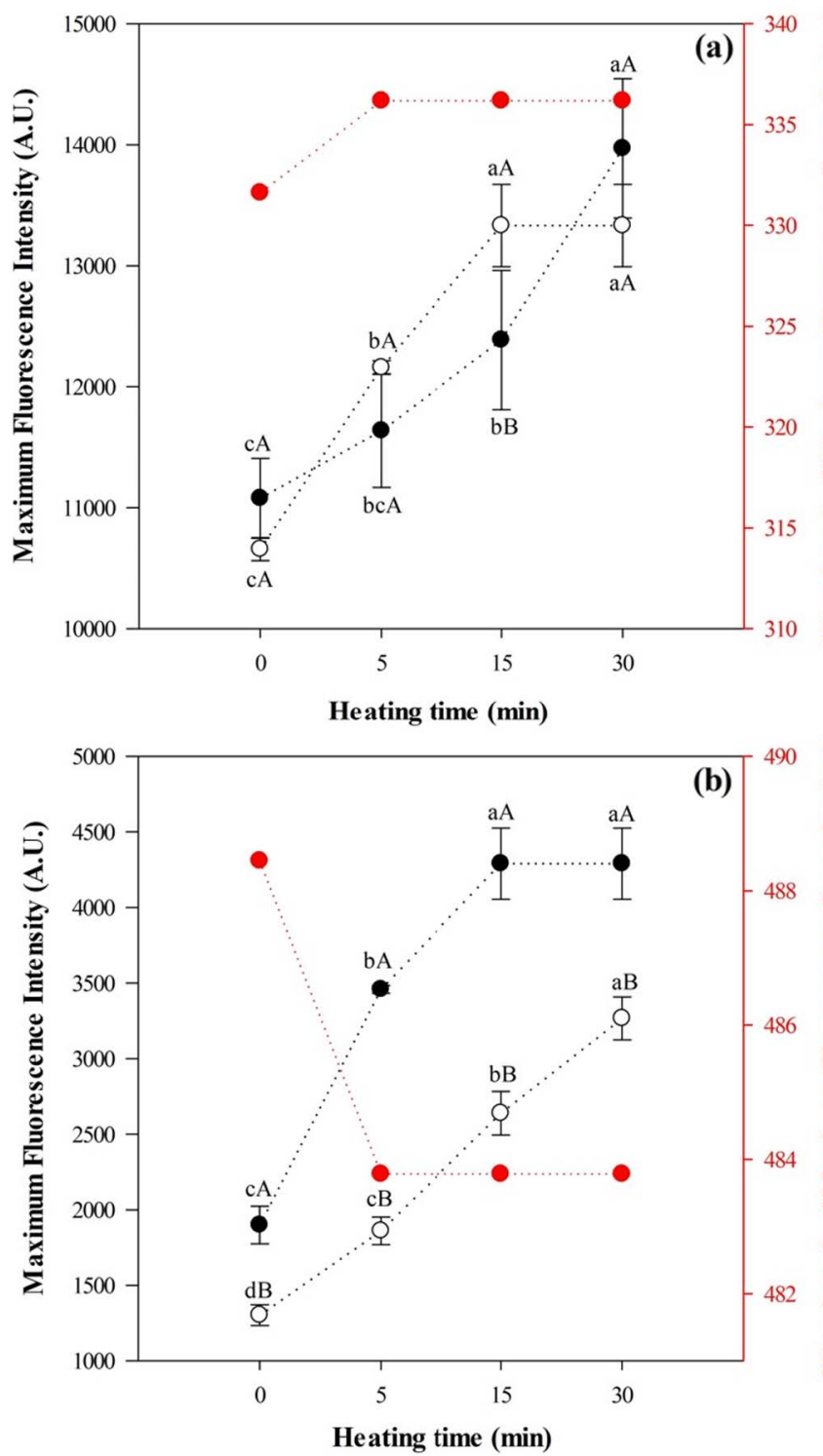

Fig. 4. Maximum fluorescence intensity and wavelength of maximum fluorescence intensity of lactoferrin dispersions after different times of conventional (full symbols) or ohmic (empty symbols) heating for intrinsic (a) and ANS (b) fluorescence. Different lowercase letters represent significant differences $(p<0.05)$ between heating time and different uppercase letters represent significant differences $(p<0.05)$ between heating treatments.

sulfhydryl groups (Lönnerdal \& Suzuki, 2013). However, results from Fig. 5 show that upon heating SH groups of lactoferrin become available to react with DTNB reagent. This gives an indication that the lactoferrin unfolding occurred under the applied heating treatments, thus exposing their $\mathrm{SH}$ groups initially inaccessible in the native protein structure, which is in agreement with a previous work regarding heatinduced changes of lactoferrin (Brisson, Britten, \& Pouliot, 2007). Unfolding of lactoferrin in respect to the SH groups was apparently very similar between $\mathrm{OH}$ and $\mathrm{CH}$ treatments. A statistically significant difference was observed for the $\mathrm{OH}$ and $\mathrm{CH}$ treatments after $30 \mathrm{~min}$ of heating despite these values being very close to each other. This may be linked with the development of protein aggregates.

Circular dichroism (CD) spectroscopy was used to investigate the changes in the secondary structure of the proteins, considering that the major elements ( $\alpha$-helix, $\beta$-sheet and coil) have characteristic CD spectra. The $\alpha$-helix configuration presents an intense and positive band at $190 \mathrm{~nm}$ and negative peaks at 208 and $220 \mathrm{~nm}$, while $\beta$-sheet configuration presents a negative dichroic peak with a minimum in the

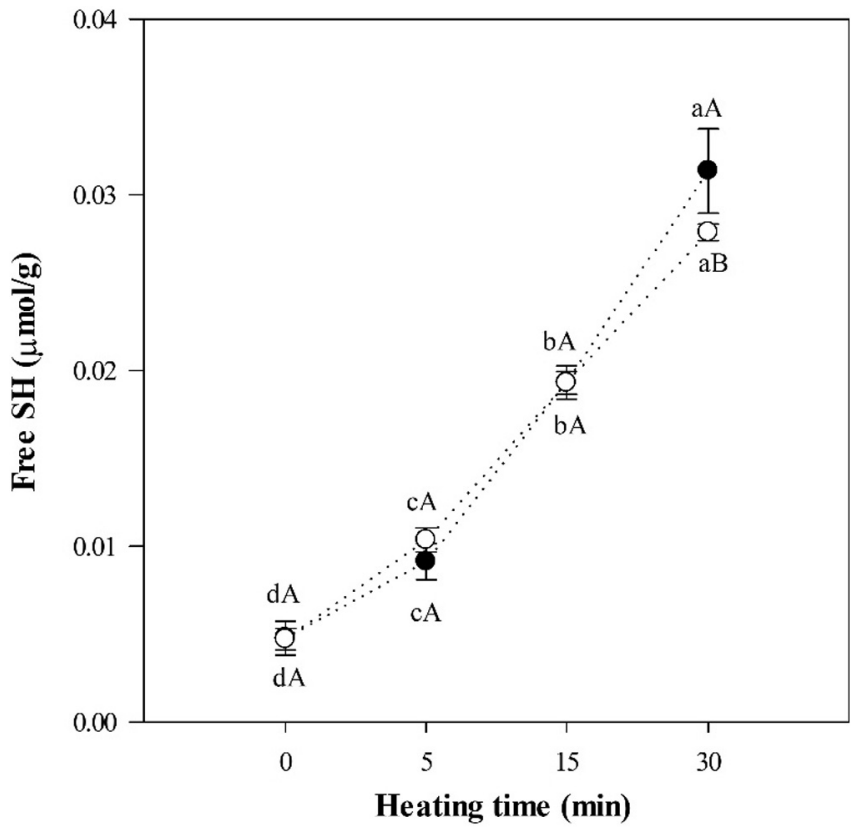

Fig. 5. Concentration of free sulfhydryl groups (SH) of lactoferrin dispersions after different times of conventional (full symbols) or ohmic (empty symbols) heating. Different lowercase letters represent significant differences $(p<0.05)$ between heating time and different uppercase letters represent significant differences $(p<0.05)$ between heating treatments.

$215 \mathrm{~nm}$ region. Random coil structures generally have a positive CD peak near $215 \mathrm{~nm}$ and a negative one near to $200 \mathrm{~nm}$ (Barreto et al., 2003; Kasinos et al., 2013). Unheated lactoferrin presented an ellipticity minimum near $210 \mathrm{~nm}$ (Fig. 6) suggesting that its structure is partially based on $\alpha$-helix and $\beta$-sheet conformation (Shimazaki, Kawano, \& Yung Choon, 1991; Stănciuc et al., 2013; Wang et al., 2013), which is in agreement with other works (Bokkhim et al., 2013; Furtado et al., 2017). CD profile of unheated lactoferrin and lactoferrin dispersions heated for $0 \mathrm{~min}$ (for both treatments) was similar, but after $30 \mathrm{~min}$ of heating, a decrease in the magnitude of ellipticity in the range of $190-210 \mathrm{~nm}$ and a slight increase in the range of $210-240 \mathrm{~nm}$ was observed for both treatments. The loss of magnitude in CD signal can be attributed to aggregation (Ioannou, Donald, \& Tromp, 2015), which corroborates results presented above. Samples heated by $\mathrm{OH}$ showed a higher loss of magnitude in $\mathrm{CD}$ signal in the range of 210-240 nm when compared to $\mathrm{CH}$. It has been suggested that the presence of moderate electric fields during heating may change not only the number of globular protein aggregates but also their shape or volume (Pereira et al., 2016), and this may have contributed to differences observed in dichroic signals among the heating treatments.

Based on results presented above, this lower aggregation observed for heat treated lactoferrin by the ohmic system when compared to conventional heating has been reported in the literature for whey proteins, where it is suggested that the application of moderate electric fields may be linked to conformational disturbances on tertiary protein structure; reorientation of hydrophobic clusters occurring in the protein structure; modification of the molecular environment due to the increased number of ions, and their different distributions around the protein molecules; and splitting of large protein aggregates (Pereira et al., 2010; Pereira et al., 2016; Rodrigues et al., 2015). Furthermore, the electric field may also affect the ionic movement in the medium (Castro, Macedo, Teixeira, \& Vicente, 2004), interfering with electrostatic interactions which play a fundamental role in folding, conformational stability and protein-protein interactions (NevesPetersen \& Petersen, 2003). Among these hypothesis, results show that the presence of an electric field during thermal denaturation seems to affect in a very distinctive way the hydrophobic core or local 


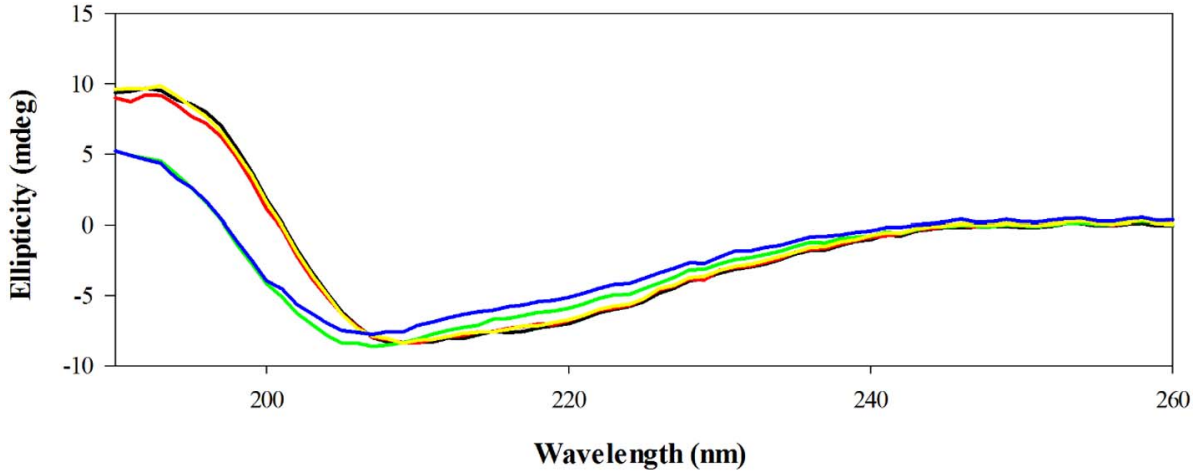

Fig. 6. Far UV-CD spectra of lactoferrin dispersions after different times of $\mathrm{CH}$ or $\mathrm{OH}$ : unheated lactoferrin (black line), lactoferrin in $\mathrm{CH}$ for $0 \mathrm{~min}$ (red line), lactoferrin in $\mathrm{CH}$ for $30 \mathrm{~min}$ (green line), lactoferrin in $\mathrm{OH}$ for $0 \mathrm{~min}$ (yellow line) and lactoferrin in $\mathrm{OH}$ for $30 \mathrm{~min}$ (blue line). (For interpretation of the references to colour in this figure legend, the reader is referred to the web version of this article.)

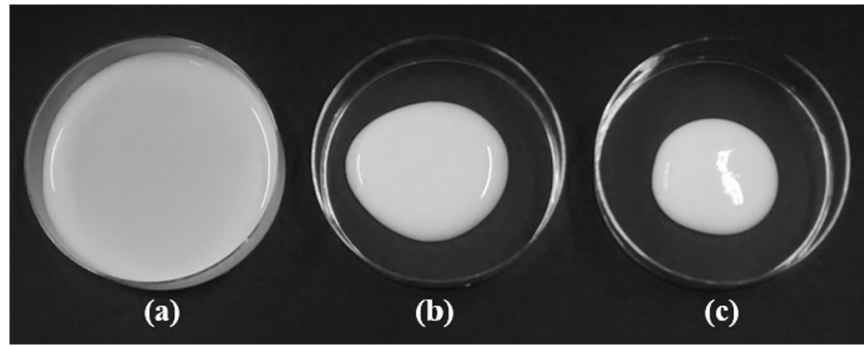

Fig. 7. Visual aspect of the emulsions produced with unheated (a), OH-heated (b) and $\mathrm{CH}$-heated (c) lactoferrin dispersions after one day of storage at room temperature.

Table 1

Rheological parameters of the emulsions produced with unheated (A), OH-heated (B) and $\mathrm{CH}$-heated (C) lactoferrin dispersion.

\begin{tabular}{lllll}
\hline Emulsion & $\eta(\mathrm{mPa} \cdot \mathrm{s})$ & $k\left(\mathrm{~Pa} \cdot \mathrm{s}^{\mathrm{n}}\right)$ & $n$ & $\mathrm{R}^{2}$ \\
\hline (A) & $1.68 \pm 0.12^{\mathrm{c}}$ & - & - & 0.98 \\
(B) & $8.06 \pm 0.71^{\mathrm{b}, *}$ & $0.02 \pm 0.00^{\mathrm{b}}$ & $0.82 \pm 0.01^{\mathrm{a}}$ & 0.99 \\
(C) & $29.51 \pm 3.47^{\mathrm{a}, *}$ & $0.31 \pm 0.1^{\mathrm{a}}$ & $0.49 \pm 0.05^{\mathrm{b}}$ & 0.99 \\
\hline
\end{tabular}

Identical small letters in the same column indicate that there are no statistically significant differences $(p>0.05)$.

${ }^{*}$ In this case the value corresponds to the apparent viscosity at $100 \mathrm{~s}^{-1}\left(\eta_{100}\right)$.

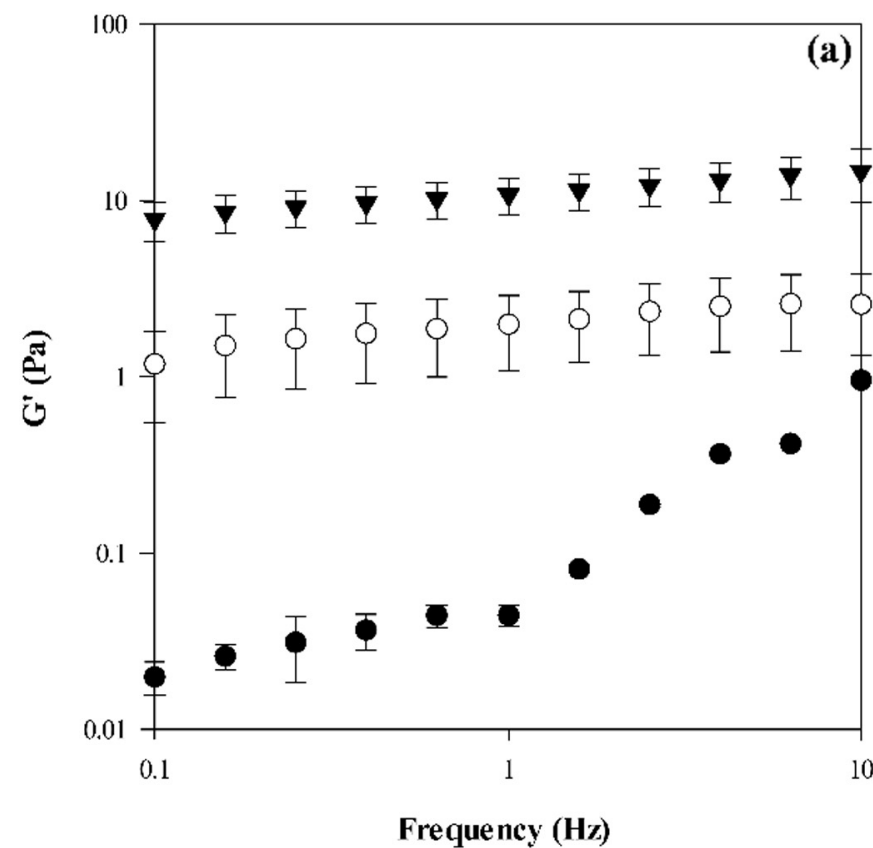

hydrophobic groups of lactoferrin. These local disturbances may have contributed to a distinct form of aggregation or interaction between unfolded molecules, once it is recognized that the way how hydrophobic groups are exposed during the initial stage of denaturation can have a crucial role on the mechanism of protein aggregation (Wijayanti, Bansal, \& Deeth, 2014). These events may explain the apparent smaller or different type of protein aggregates, as well as the distribution of protein secondary structures found under the influence of $\mathrm{OH}$.

\subsection{Characterization of cold gel-like emulsions}

Fig. 7 shows the visual aspect of the emulsions produced with unheated lactoferrin dispersion and lactoferrin heated by $\mathrm{OH}$ and $\mathrm{CH}$ after one day of storage at room temperature. It was observed that for both heating treatments the emulsions showed a soft gel-like appearance, while the emulsion produced with unheated lactoferrin remained in a liquid state (Fig. 7). Similar appearance was observed in emulsions produced with whey proteins (Liu \& Tang, 2011; Manoi \& Rizvi, 2009), but the network structure seems to be denser for the later.

When submitted to rheological analysis, emulsions produced with unheated lactoferrin dispersion showed Newtonian behavior, while emulsions produced with lactoferrin heated by $\mathrm{OH}$ or $\mathrm{CH}$ showed a shear-thinning behavior (Table 1). Such shear thinning behavior is related to flocculation of oil droplets forming a network of aggregated droplets due to protein matrix (Boutin et al., 2007; Liu \& Tang, 2011;

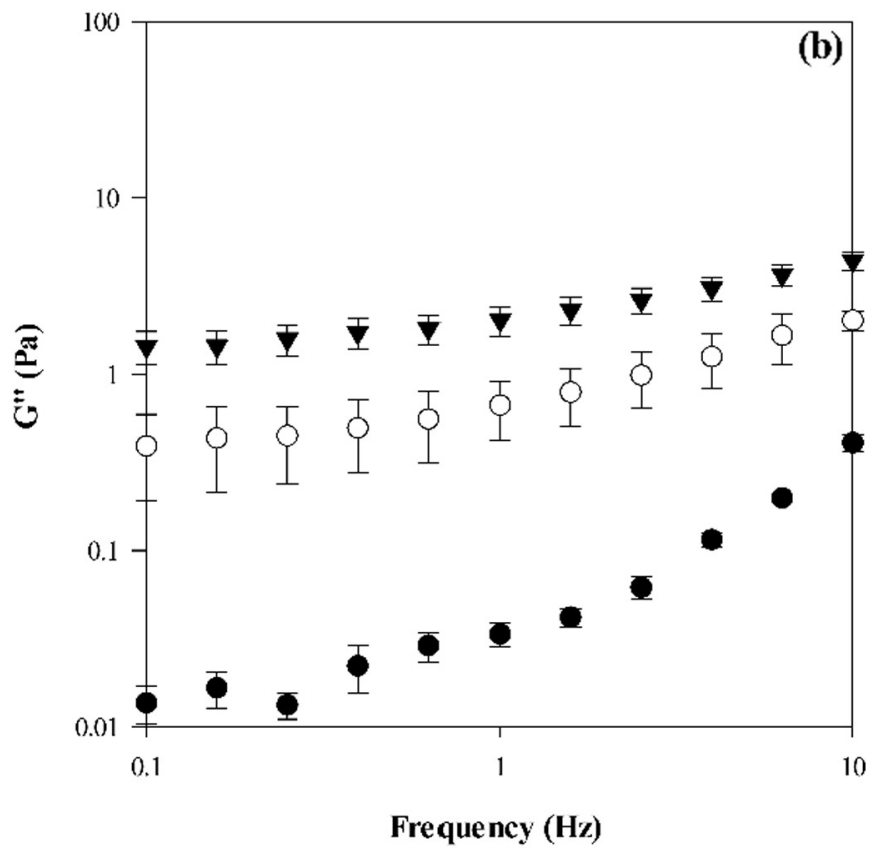

Fig. 8. Storage $\left(G^{\prime}\right)$ (a) and loss $\left(G^{\prime \prime}\right)$ (b) moduli of the emulsions produced with unheated $(\boldsymbol{\bullet})$, OH-heated $(\mathrm{O})$ and $\mathrm{CH}$-heated $(\boldsymbol{\nabla})$ lactoferrin dispersions. 

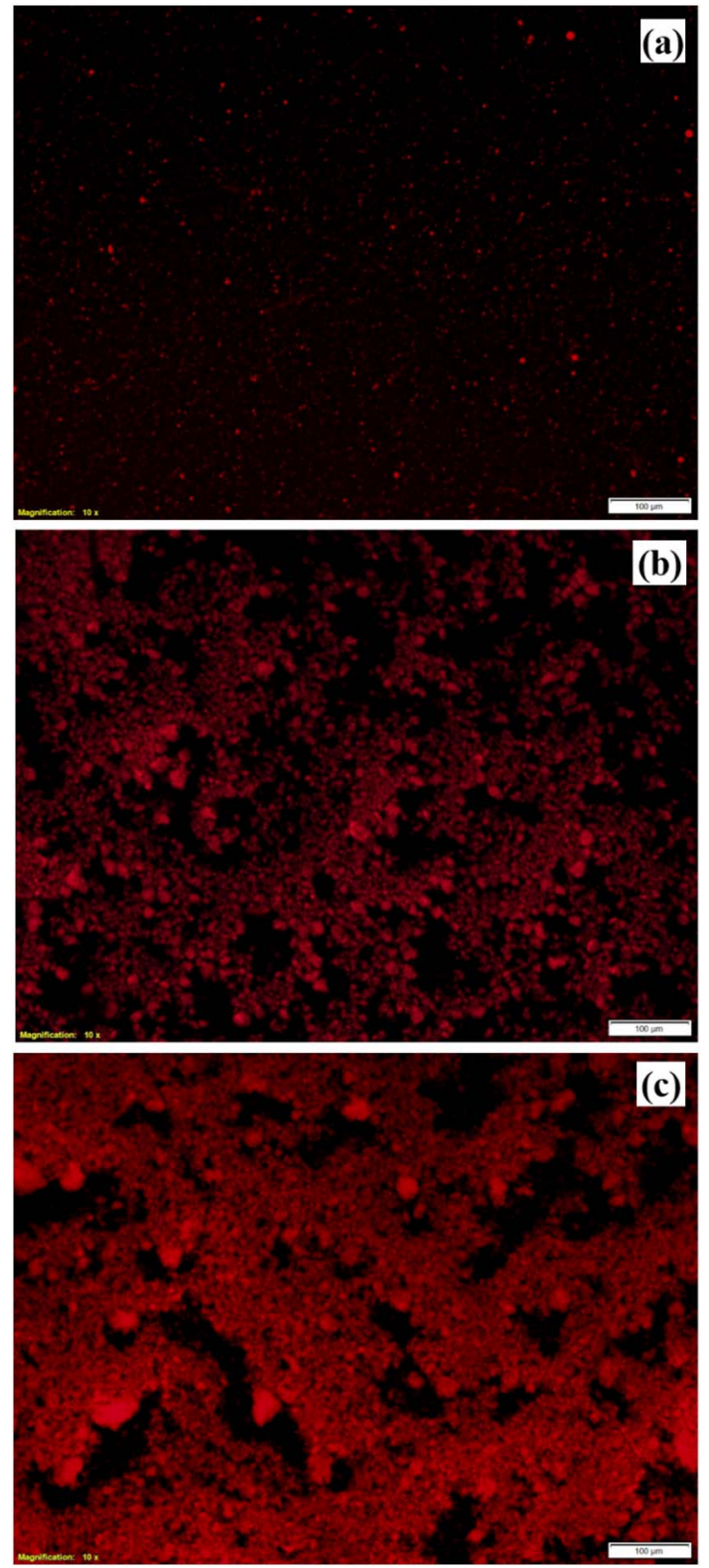

Fig. 9. Microstructure of the emulsions produced with unheated (a), OH-heated (b) and CH-heated (c) lactoferrin dispersions. Scale bar: $100 \mu \mathrm{m}$

Manoi \& Rizvi, 2009). Viscosity values ( $\eta$ ) (Table 1 ) showed a statistically significant increase $(p<0.05)$ for heat treated emulsions, being this increase more pronounced for lactoferrin heated by the conventional system, which confirms the increase of emulsion structuration due to a probably higher interaction among the droplets (through the formation of new inter- and intramolecular disulfide bonds that will engage toward protein aggregation, besides electrostatic and hydrophobic interactions between them).

Viscoelastic properties were determined, once the ratio between storage $\left(G^{\prime}\right)$ and loss $\left(G^{\prime \prime}\right)$ moduli may indicate if the emulsion is strongly or weakly associated (Torres, Iturbe, Snowden, Chowdhry, \& Leharne, 2007). The viscoelastic properties of the emulsions produced with unheated lactoferrin dispersion, lactoferrin heated by $\mathrm{OH}$ and $\mathrm{CH}$ after one day of storage at room temperature are presented in Fig. 8. Mechanical spectra of the emulsions indicate that emulsions heated by ohmic or conventional systems presented a gel-like behavior ( $G^{\prime}$ higher than $G^{\prime \prime}$ throughout the frequency range). Somehow, the emulsion produced with lactoferrin heated by the conventional system resulted in the strongest gel-like structure - i.e. $G^{\prime}$ values were 10 times greater than those obtained for emulsions produced with lactoferrin heated by the ohmic system and almost 1000 times greater than those obtained for emulsions produced with unheated lactoferrin (for low frequency values, 0.1-1). On the other hand, it was observed only a slight increase in the moduli of heat treated samples for increasing values of frequency, which has been attributed to a predominantly solid behavior of the gel-like emulsions, indicating that they may formed permanent interactions (Liu\& Tang, 2011). However, the elastic modulus $\left(G^{\prime}\right)$ of the emulsions produced with unheated lactoferrin showed a frequency-dependence, which is associated to a weaker gel or a less stable emulsion (Torres et al., 2007). Furthermore, the network entanglement between adsorbed and nonadsorbed protein molecules is the main factor that leads to high elastic modulus values and a gel-like structure (Dickinson \& Hong, 1995).

The emulsion prepared with unheated lactoferrin presented droplet size around $206 \pm 2 \mathrm{~nm}$, but it was not possible to measure the droplet size of the other systems due to the intense aggregation observed. In order to confirm aggregation of oil droplets, the microstructure of the emulsions produced with unheated and heated lactoferrin dispersions was analyzed, and the corresponding pictures are shown in Fig. 9. Emulsions presented remarkable differences depending on the heating treatment. The oil droplets of the emulsions produced with unheated lactoferrin were homogeneously distributed in the aqueous protein phase with no signs of flocculation/aggregation. However, oil droplets entrapped in an entangled protein network was observed for emulsions produced with heat treated protein. Besides the heat aggregation of the proteins, salt addition also contributed to the formation of this particulate structure composed of random aggregates (Sok Line et al., 2005). Microscopic images suggest a denser network for emulsions produced with lactoferrin dispersions heated by the conventional system. These images confirm rheology results and corroborate protein characterization results (Section 3.1). Furthermore, the differences between the microstructures are reflecting the differences in interactive forces involved in the formation of the cold gel-like emulsions.

\section{Conclusions}

Cold gel-like emulsions were produced using lactoferrin dispersions subjected to a heat pretreatment in an ohmic or conventional system. Their formation was associated to the good emulsifying capacity of lactoferrin combined with heat treatment of the protein. Both $\mathrm{OH}$ and $\mathrm{CH}$ influenced thermal unfolding and aggregation of lactoferrin molecules. However, internal electrical heating and the existence of nonthermal effects - i.e. electric field - possibly affected the molecular flexibility or stability of hydrophobic groups of lactoferrin. $\mathrm{OH}$ led to less aggregated protein molecules, when compared to conventional heating. Such different aggregation pattern was confirmed by a lower increase in particle size, turbidity, intrinsic and extrinsic fluorescence and a distinct dichroic signal. These events had a direct impact on structural and mechanical properties of the prepared emulsions. Therefore, the rheological and microstructural properties depended on the heat treatment applied, since conventional heating produced stronger gel-like emulsions than $\mathrm{OH}$ treatment. $\mathrm{OH}$ appears to be an efficient heating technology that can be used to modulate lactoferrin thermal denaturation and lead to distinct gel-like emulsions. These emulsions could be interesting for several innovative food applications, i.e. as texturizers, fat replacers, carrier of heat-sensitive and lipid-soluble bioactives. The results from this study also suggest a further fundamental approach about the influence of electrical variables of ohmic heating technology on the stability and functionality of lactoferrin molecules. Ohmic heating seems to impose small structural changes at the nanoscale level that can have a major impact on the macrostructural and functional properties of globular proteins. 


\section{Acknowledgements}

Authors would like to thank National Council for Scientific and Technological Development (CNPq) for the PhD fellowship (140271/ 2014-7) and for the research grant (307168/2016-6). This study was also supported by the Portuguese Foundation for Science and Technology (FCT) under the scope of the strategic funding of UID/BIO/ 04469/2013 unit and COMPETE 2020 (POCI-01-0145-FEDER-006684) and BioTecNorte operation (NORTE-01-0145-FEDER-000004) funded by European Regional Development Fund under the scope of Norte2020 - Programa Operacional Regional do Norte. Ricardo N. Pereira gratefully acknowledge to FCT the financial grant with reference SFRH/ BPD/81887/2011. We also acknowledge Synlait Milk Ltd. for the donation of lactoferrin samples.

\section{References}

Anema, S. G., \& Li, Y. (2003). Association of denatured whey proteins with casein micelles in heated reconstituted skim milk and its effect on casein micelle size. Journal of Dairy Research, 70(1), 73-83. http://dx.doi.org/10.1017/S0022029902005903.

Barreto, P. L. M., Roeder, J., Crespo, J. S., Maciel, G. R., Terenzi, H., Pires, A. T. N., \& Soldi, V. (2003). Effect of concentration, temperature and plasticizer content on rheological properties of sodium caseinate and sodium caseinate/sorbitol solutions and glass transition of their films. Food Chemistry, 82(3), 425-431. http://dx.doi.org/ 10.1016/S0308-8146(03)00006-2.

Bengoechea, C., Peinado, I., \& McClements, D. J. (2011). Formation of protein nanoparticles by controlled heat treatment of lactoferrin: Factors affecting particle characteristics. Food Hydrocolloids, 25(5), 1354-1360. http://dx.doi.org/10.1016/j. foodhyd.2010.12.014.

Bokkhim, H., Bansal, N., GrØndahl, L., \& Bhandari, B. (2013). Physico-chemical properties of different forms of bovine lactoferrin. Food Chemistry, 141(3), 3007-3013. http://dx.doi.org/10.1016/j.foodchem.2013.05.139.

Bourbon, A. I., Pinheiro, A. C., Carneiro-da-Cunha, M. G., Pereira, R. N., Cerqueira, M. A., \& Vicente, A. A. (2015). Development and characterization of lactoferrin-GMP nanohydrogels: Evaluation of $\mathrm{pH}$, ionic strength and temperature effect. Food Hydrocolloids, 48, 292-300. http://dx.doi.org/10.1016/j.foodhyd.2015.02.026.

Boutin, C., Giroux, H. J., Paquin, P., \& Britten, M. (2007). Characterization and acidinduced gelation of butter oil emulsions produced from heated whey protein dispersions. International Dairy Journal, 17(6), 696-703. http://dx.doi.org/10.1016/j. idairyj.2006.08.009.

Brisson, G., Britten, M., \& Pouliot, Y. (2007). Heat-induced aggregation of bovine lactoferrin at neutral pH: Effect of iron saturation. International Dairy Journal, 17(6), 617-624. http://dx.doi.org/10.1016/j.idairyj.2006.09.002.

Bryant, C. M., \& McClements, D. J. (2000). Influence of $\mathrm{NaCl}$ and $\mathrm{CaCl}_{2}$ on cold-set gelation of heat-denatured whey protein. Journal of Food Science, 65(5), 801-804. http://dx.doi.org/10.1111/j.1365-2621.2000.tb13590.x.

Castro, I., Macedo, B., Teixeira, J. A., \& Vicente, A. A. (2004). The effect of electric field on important food-processing enzymes: Comparison of inactivation kinetics under conventional and ohmic heating. Journal of Food Science, 69(9), C696-C701. http:// dx.doi.org/10.1111/j.1365-2621.2004.tb09918.x.

Castro, I., Teixeira, J. A., Salengke, S., Sastry, S. K., \& Vicente, A. A. (2003). The influence of field strength, sugar and solid content on electrical conductivity of strawberry products. Journal of Food Process Engineering, 26(1), 17-29. http://dx.doi.org/10. 1111/j.1745-4530.2003.tb00587.x.

Chen, J., Dickinson, E., Langton, M., \& Hermansson, A.-M. (2000). Mechanical properties and microstructure of heat-set whey protein emulsion gels: Effect of emulsifiers. LWT - Food Science and Technology, 33(4), 299-307. http://dx.doi.org/10.1006/fstl.2000. 0656.

Dalgleish, D. G. (1997). Adsorption of protein and the stability of emulsions. Trends in Food Science \& Technology, 8(1), 1-6. http://dx.doi.org/10.1016/S0924-2244(97) 01001-7.

Damodaran, S., Parkin, K. L., \& Fennema, O. R. (2007). Fennema's food chemistry (4th ed.). Taylor \& Francis.

De Alwis, A. A. P., \& Fryer, P. J. (1990). A finite-element analysis of heat generation and transfer during ohmic heating of food. Chemical Engineering Science, 45(6), 1547-1559. http://dx.doi.org/10.1016/0009-2509(90)80006-Z.

Dickinson, E. (1997). Properties of emulsions stabilized with milk proteins: Overview of some recent developments. Journal of Dairy Science, 80(10), 2607-2619. http://dx. doi.org/10.3168/jds.S0022-0302(97)76218-0.

Dickinson, E., \& Hong, S.-T. (1995). Influence of water-soluble nonionic emulsifier on the rheology of heat-set protein-stabilized emulsion gels. Journal of Agricultural and Food Chemistry, 43(10), 2560-2566. http://dx.doi.org/10.1021/jf00058a002.

Fang, B., Zhang, M., Tian, M., Jiang, L., Guo, H. Y., \& Ren, F. Z. (2014). Bovine lactoferrin binds oleic acid to form an anti-tumor complex similar to HAMLET. Biochimica et Biophysica Acta - Molecular and Cell Biology of Lipids, 1841(4), 535-543. http://dx.doi. org/10.1016/j.bbalip.2013.12.008.

Furtado, G.d. F., Mantovani, R. A., Consoli, L., Hubinger, M. D., \& Cunha, R. L.d. (2017). Structural and emulsifying properties of sodium caseinate and lactoferrin influenced by ultrasound process. Food Hydrocolloids, 63, 178-188. http://dx.doi.org/10.1016/j. foodhyd.2016.08.038.
Ioannou, J. C., Donald, A. M., \& Tromp, R. H. (2015). Characterising the secondary structure changes occurring in high density systems of BLG dissolved in aqueous $\mathrm{pH} 3$ buffer. Food Hydrocolloids, 46, 216-225. http://dx.doi.org/10.1016/j.foodhyd.2014. 12.027.

Kasinos, M., Sabatino, P., Vanloo, B., Gevaert, K., Martins, J. C., \& Van der Meeren, P. (2013). Effect of phospholipid molecular structure on its interaction with whey proteins in aqueous solution. Food Hydrocolloids, 32(2), 312-321. http://dx.doi.org/ 10.1016/j.foodhyd.2013.01.007.

Kuhn, K. R., Cavallieri, Â. L. F., \& Da Cunha, R. L. (2010). Cold-set whey protein gels induced by calcium or sodium salt addition. International Journal of Food Science and Technology, 45(2), 348-357. http://dx.doi.org/10.1111/j.1365-2621.2009.02145.x.

Kuhn, K. R., Cavallieri, Â. L. F., \& da Cunha, R. L. (2011). Cold-set whey protein-flaxseed gum gels induced by mono or divalent salt addition. Food Hydrocolloids, 25(5), 1302-1310. http://dx.doi.org/10.1016/j.foodhyd.2010.12.005.

Lee, H. A., Choi, S. J., \& Moon, T. W. (2006). Characteristics of sodium caseinate- and soy protein isolate-stabilized emulsion-gels formed by microbial transglutaminase. Journal of Food Science, 71(6), C352-C357. http://dx.doi.org/10.1111/j.1750-3841. 2006.00110.x.

Liu, F., \& Tang, C.-H. (2011). Cold, gel-like whey protein emulsions by microfluidisation emulsification: Rheological properties and microstructures. Food Chemistry, 127(4), 1641-1647. http://dx.doi.org/10.1016/j.foodchem.2011.02.031.

Lönnerdal, B., \& Suzuki, Y. A. (2013). Lactoferrin. In P. L. H. McSweeney, \& P. F. Fox (Eds.). Advanced dairy chemistry: Volume 1A: Proteins: Basic aspects (pp. 295-315). (4th ed.). Boston, MA: Springer US.

Machado, L. F., Pereira, R. N., Martins, R. C., Teixeira, J. A., \& Vicente, A. A. (2010). Moderate electric fields can inactivate Escherichia coli at room temperature. Journal of Food Engineering, 96(4), 520-527. http://dx.doi.org/10.1016/j.jfoodeng.2009.08. 035.

Manoi, K., \& Rizvi, S. S. H. (2009). Emulsification mechanisms and characterizations of cold, gel-like emulsions produced from texturized whey protein concentrate. Food Hydrocolloids, 23(7), 1837-1847. http://dx.doi.org/10.1016/j.foodhyd.2009.02.011.

McClements, D. J., Decker, E. A., \& Weiss, J. (2007). Emulsion-based delivery systems for lipophilic bioactive components. Journal of Food Science, 72(8), R109-R124. http:// dx.doi.org/10.1111/j.1750-3841.2007.00507.x.

Neves-Petersen, M. T., \& Petersen, S. B. (2003). Protein electrostatics: A review of the equations and methods used to model electrostatic equations in biomolecules Applications in biotechnology. Biotechnology annual review: Vol. 9, (pp. 315-395). Elsevier.

Nielsen, B. T., Singh, H., \& Latham, J. M. (1996). Aggregation of bovine $\beta$-lactoglobulins $\mathrm{A}$ and B on heating at $75^{\circ} \mathrm{C}$. International Dairy Journal, 6(5), 519-527. http://dx.doi. org/10.1016/0958-6946(95)00022-4.

Pereira, R. N., Rodrigues, R. M., Altinok, E., Ramos, Ó. L., Xavier Malcata, F., Maresca, P., \& Vicente, A. A. (2017). Development of iron-rich whey protein hydrogels following application of ohmic heating - Effects of moderate electric fields. Food Research International, 99(Part 1), 435-443. http://dx.doi.org/10.1016/j.foodres.2017.05. 023.

Pereira, R. N., Rodrigues, R. M., Ramos, Ó. L., Xavier Malcata, F., Teixeira, J. A., \& Vicente, A. A. (2016). Production of whey protein-based aggregates under ohmic heating. Food and Bioprocess Technology, 9(4), 576-587. http://dx.doi.org/10.1007/ s11947-015-1651-4.

Pereira, R. N., Souza, B. W. S., Cerqueira, M. A., Teixeira, J. A., \& Vicente, A. A. (2010). Effects of electric fields on protein unfolding and aggregation: Influence on edible films formation. Biomacromolecules, 11(11), 2912-2918. http://dx.doi.org/10.1021/ bm100681a.

Pereira, R. N., Teixeira, J. A., \& Vicente, A. A. (2011). Exploring the denaturation of whey proteins upon application of moderate electric fields: A kinetic and thermodynamic study. Journal of Agricultural and Food Chemistry, 59(21), 11589-11597. http://dx. doi.org/10.1021/jf201727s.

Pinheiro, A. C., Coimbra, M. A., \& Vicente, A. A. (2016). In vitro behaviour of curcumin nanoemulsions stabilized by biopolymer emulsifiers - Effect of interfacial composition. Food Hydrocolloids, 52, 460-467. http://dx.doi.org/10.1016/j.foodhyd.2015.07. 025.

Rodrigues, R. M., Martins, A. J., Ramos, O. L., Malcata, F. X., Teixeira, J. A., Vicente, A. A., \& Pereira, R. N. (2015). Influence of moderate electric fields on gelation of whey protein isolate. Food Hydrocolloids, 43, 329-339. http://dx.doi.org/10.1016/j. foodhyd.2014.06.002.

Royer, C. A. (2006). Probing protein folding and conformational transitions with fluorescence. Chemical Reviews, 106(5), 1769-1784. http://dx.doi.org/10.1021/ cr0404390.

Sarkar, A., Goh, K. K. T., \& Singh, H. (2009). Colloidal stability and interactions of milkprotein-stabilized emulsions in an artificial saliva. Food Hydrocolloids, 23(5), 1270-1278. http://dx.doi.org/10.1016/j.foodhyd.2008.09.008.

Sarkar, A., Horne, D. S., \& Singh, H. (2010). Interactions of milk protein-stabilized oil-inwater emulsions with bile salts in a simulated upper intestinal model. Food Hydrocolloids, 24(2-3), 142-151. http://dx.doi.org/10.1016/j.foodhyd.2009.08.012.

Shimazaki, K.-I., Kawano, N., \& Yung Choon, Y. (1991). Comparison of bovine, sheep and goat milk lactoferrins in their electrophoretic behavior, conformation, immunochemical properties and lectin reactivity. Comparative Biochemistry and Physiology Part B: Comparative Biochemistry, 98(2), 417-422. http://dx.doi.org/10. 1016/0305-0491(91)90199-N.

Sok Line, V. L., Remondetto, G. E., \& Subirade, M. (2005). Cold gelation of $\beta$-lactoglobulin oil-in-water emulsions. Food Hydrocolloids, 19(2), 269-278. http://dx.doi.org/10. 1016/j.foodhyd.2004.06.004.

Spik, G., Coddeville, B., Mazurier, J., Bourne, Y., Cambillaut, C., \& Montreuil, J. (1994). Primary and three-dimensional structure of lactotransferrin (lactoferrin) glycans. In T. W. Hutchens, S. Rumball, \& B. Lönnerdal (Vol. Eds.), Lactoferrin. Vol. 357. 
Lactoferrin (pp. 21-32). US: Springer.

Stănciuc, N., Aprodu, I., Râpeanu, G., van der Plancken, I., Bahrim, G., \& Hendrickx, M. (2013). Analysis of the thermally induced structural changes of bovine lactoferrin. Journal of Agricultural and Food Chemistry, 61(9), 2234-2243. http://dx.doi.org/10. 1021/jf305178s.

Steijns, J. M., \& van Hooijdonk, A. C. M. (2000). Occurrence, structure, biochemical properties and technological characteristics of lactoferrin. British Journal of Nutrition, 84(S1), 11-17. http://dx.doi.org/10.1017/S0007114500002191.

Stroylova, Y. Y., Zimny, J., Yousefi, R., Chobert, J.-M., Jakubowski, H., Muronetz, V. I., \& Haertlé, T. (2011). Aggregation and structural changes of $\alpha S 1-, \beta$ - and $\kappa$-caseins induced by homocysteinylation. Biochimica et Biophysica Acta (BBA) - Proteins and Proteomics, 1814(10), 1234-1245. http://dx.doi.org/10.1016/j.bbapap.2011.05.017.

Tavares, G. M., Croguennec, T., Lê, S., Lerideau, O., Hamon, P., Carvalho, A. F., \& Bouhallab, S. (2015). Binding of folic acid induces specific self-aggregation of lactoferrin: Thermodynamic characterization. Langmuir, 31(45), 12481-12488. http:// dx.doi.org/10.1021/acs.langmuir.5b02299.

Tokle, T., \& McClements, D. J. (2011). Physicochemical properties of lactoferrin stabilized oil-in-water emulsions: Effects of $\mathrm{pH}$, salt and heating. Food Hydrocolloids, 25(5), 976-982. http://dx.doi.org/10.1016/j.foodhyd.2010.09.012.

Torres, L. G., Iturbe, R., Snowden, M. J., Chowdhry, B. Z., \& Leharne, S. A. (2007). Preparation of $\mathrm{o} / \mathrm{w}$ emulsions stabilized by solid particles and their characterization by oscillatory rheology. Colloids and Surfaces A: Physicochemical and Engineering
Aspects, 302(1-3), 439-448. http://dx.doi.org/10.1016/j.colsurfa.2007.03.009. Uversky, V. N., Narizhneva, N. V., Kirschstein, S. O., Winter, S., \& Löber, G. (1997). Conformational transitions provoked by organic solvents in $\beta$-lactoglobulin: Can a molten globule like intermediate be induced by the decrease in dielectric constant? Folding and Design, 2(3), 163-172. http://dx.doi.org/10.1016/S1359-0278(97) 00023-0.

Vivian, J. T., \& Callis, P. R. (2001). Mechanisms of tryptophan fluorescence shifts in proteins. Biophysical Journal, 80(5), 2093-2109. http://dx.doi.org/10.1016/S00063495(01)76183-8.

Wakabayashi, H., Yamauchi, K., \& Takase, M. (2006). Lactoferrin research, technology and applications. International Dairy Journal, 16(11), 1241-1251. http://dx.doi.org/ 10.1016/j.idairyj.2006.06.013.

Wang, X. Y., Guo, H. Y., Zhang, W., Wen, P. C., Zhang, H., Guo, Z. R., \& Ren, F. Z. (2013). Effect of iron saturation level of lactoferrin on osteogenic activity in vitro and in vivo. Journal of Dairy Science, 96(1), 33-39. http://dx.doi.org/10.3168/jds.2012-5692.

Wijayanti, H. B., Bansal, N., \& Deeth, H. C. (2014). Stability of whey proteins during thermal processing: A review. Comprehensive Reviews in Food Science and Food Safety, 13(6), 1235-1251. http://dx.doi.org/10.1111/1541-4337.12105.

Ye, A., \& Taylor, S. (2009). Characterization of cold-set gels produced from heated emulsions stabilized by whey protein. International Dairy Journal, 19(12), 721-727. http://dx.doi.org/10.1016/j.idairyj.2009.06.003. 